among metamorphic rocks, that various structures, which can only be dne to the deposition of the original materials, are by no means unfrequent, especially among the higher groups. But while thus defending myself from an implied charge of error, I am glad to take the opportunity of expressing my full concurrence in the general conclusions of these valuable papers. They contain a very lucid exposition of the principles on which mountain chains have been produced, and I expect that in the main the 'Secret of the Highlands' has been discovered. The analogies between the Highlands and the Alps are in many respects close; but their ' mountain making' belongs to very different epochs of geological time, so that they are in very different stages of their history. In each wo have a great nucleus of Archæan rocks containing more than one group. In the Alps the next great period of deposit on record ( $I$ do not forget the Carboniferous strata of the west) was throughout the Mesozoic, continuing to the earlier Kainozoic. In the Highlands the corresponding period was the earlier Palæozoic. As the Alps became a mountain-chain in Pre-Miocene days, so did the Highlands in PreDevonian. There is also a close analogy between the Old Red Sandstone of the latter and the Nagelflue and Molasse of the former. Possibly we may even extend our comparison to the marcrinal volcanic deposits of the two; but be this as it may, there is I think little doubt that to interpret the Highlands as a greatly denuded mountain-chain is the most hopeful way out of the puzzles which their rocks afford.

T. G. Bonney.

\title{
MR. WALLACE'S REPLY TO MR. T. MELLARD READE ON THE
} AGE OF 'THE EARTH.

SIR,-I have just received from Mr. T. Mellard Reade, F.G.S., a copy of his paper on the "Age of the Earth" (which appeared in your Magazine of July last), in which I am asked to put that gentleman right as regards what he calls his "analysis" of some figures and estimates given in my "Island Life"; and I gladly seize the first opportunity of doing so. To aroid the necessity of repeating my own statements as well as those of Mr. Reacle, I must ask the reader who is interested in this matter to refer back to the above-mentioned article.

The first statement of Mr. Reade's which I have to "put right" is the following:- "It is evident, if the figures mean anything at all, that three millions of square miles 177,200 feet thick represent the whole of the rock removed by denudation in all forms since the geological history of the earth began. Spread this over 57 million square miles of land and we get a deposit 9326 feet thick deposited in all geological time." This is not quite an accurate representation of my statements. The figures quoted represent, not the whole matter denuded, but only that portion of which a record still exists in the rocks; and this matter has been deposited, not "in all geological time," but only in that portion of geological time indicated by the known series of stratified rocks; unconformities and other breaks representing unknown intervals of which we have no 
record. With these corrections the figures used by me do imply what Mr. Reade says they do; which is, in other words,- - that the average thickness of that portion of the earth's crust formed by the known stratified rocks does not probably exceed nine or ten thousand feet.

Mr. Reade, however, without directly impugning these figures, attempts to show that they lead to absurd or incredible results, and he does this by manipulating them in a way which is altogether beyond my comprehension. He first says, that these rocks have been made and destroyed over and over again; and then argues that, because the exposed igneous rocks cover about $\frac{1}{12}$ of the land surface, therefore "each particle of rock, on the average, has been denuded and laid down at least twelve times." I have in vain tried to see any connection between these two statements, but what follows is still more unintelligible. Mr. Reade adds:-“"From this it follows that the actual thickness of the sedimentary crust of the earth, if there were no sedimentary rocks except on the site of the present land


$\overline{9} \frac{1}{3} \frac{2}{6}$ instead of $\frac{93}{1} \frac{20}{2}$, this means that, because the stratified rocks have been successively formed from the denudation of older rocks (stratified and igneous), therefore their actual thickness would be many times less than by estimates founded on direct measurement it is known they actually are! It is, I think, evident that, from Mr. Reade's point of view, he should have here multiplied instead of divided by 12. For if the older rocks have been reduced in thickness by denudation, and their débris has gone to form newer rocks in each successive epoch, it is clear that when first deposited all the rocks voould have been thicker than now, though there is no definite relation between the number of successive formations and their greater thickness, as Mr. Reade seems to suppose. For example, if half the original Palæozoic rocks have been denuded to form the Mesozoic and parts of the later rocks, and half of the original Mesozoic to form the Tertiary, and half these again to form glicial and recent deposits, each would have been at first about twice as thick as it is now,- - not one-fourth the thickness, as Mr. Reade's mode of calculation would make them; and as the whole problem is one of the time taken to produce these various deposits, the greater original thickness would have to be used in the calculation.

But, even if Mr. Reade's figures are thus corrected, his whole criticism is radically unsound; for, as I have explained in $m y$ original discussion of the subject, denudation is so unequal in its action and occurs so generally on the edges of uplifted strata not over their surfaces of deposit, that it would be quite possible for $\frac{9}{10}$ or even $\frac{9 n}{100}$ of a formation to be destroyed by denudation, and yet for the remaining $-\frac{1}{10}$ or $\frac{2}{100}$ to give a fairly accurate measure of the average thickness or even sometimes of a maximum thickness of the original deposit. Our measures of the thickness of the sedimentary rocks will, therefore, not be seriously affected by the fact that by far the larger portion of all of them have been destroyed by denudation, and again and again laid down to form newer rocks; and as I have 
used measures of the maximum thicknesses, I have considered that these would in all probability not differ much from the original average thicknesses of the same rocks before they had suffered denudation. No doubt some rocks may have been wholly destroyed by denudation, or are so covered up by later deposits as to be beyond our reach, and to allow for these $I$ am willing to admit that my estimate of the whole thickness of the rocks, and therefore of the time taken to produce them, may have to be considerably increased; but this would bring my figures nearer to those usually arrived at, not enormously further from them as Mr. Reade endeavours to prove.

Yet again, Mr. Reade points out that continents have fluctuated, and have sometimes been larger than now. To allow for this he doubles the land surface and reduces the corresponding thickness of the strata to one-half! But, surely, if the continents have been sometimes larger, they have also been sometimes smaller, and I see no reason to think we can take any fairer average than that of the present area; and even if the average $h a d$ been double, then the denudation and the deposit would presumably have been double also, not half as Mr. Reade suggests.

With regard to my fundamental position-that the areas of deposition are (and always have been) very much smaller than the areas of denudation, and that, in making any estimate of geological time founded on the thickness of the sedimentary rocks and the known rate of denudation, this fact must be taken account of, Mr. Reade makes no objection; and, whatever "confusion of ideas" may have pervaded my estimate, the subject has certainly not been rendered clearer by his criticism.

Finally, as regards the general theory of the "Permanence of Oceans and Continents" (or, more properly, of Oceanic and Continental areas), which Mr. Reade somewhat sneeringly remarks "is now becoming fashionable,"-it is time that its opponents should give up petty criticism of unimportant details or collateral issues, which have little bearing on the main question, and attempt to grapple with the whole body of facts and arguments adduced in its support by some of the first geologists of the day, and which I have endeavoured to set forth in a connected form in the pages of "Island Life." Any such general examination of the question from an adverse point of view, I have hitherto failed to meet with.

Alfred R. Wallace.

\section{THE OLD HYTHE PINNACLE OF CHALK.}

Sin,-On referring to the Life of Lyell, I find the letter relating to the disappearance of the Old Hythe Pinnacle of Chalk was written in 1869 , not 1864 . The evidence of Lyell does not therefore conflict with that of Prof. Seeley and Mr. Searles Wood, as I thought it did, but taken with theirs, rather points to the total destruction of the pinnacle between those dates. With this correction I must close the correspondence on this subject so far as I am concerned.

Sept. 4, 1883.

T. Mellakd Reade. 